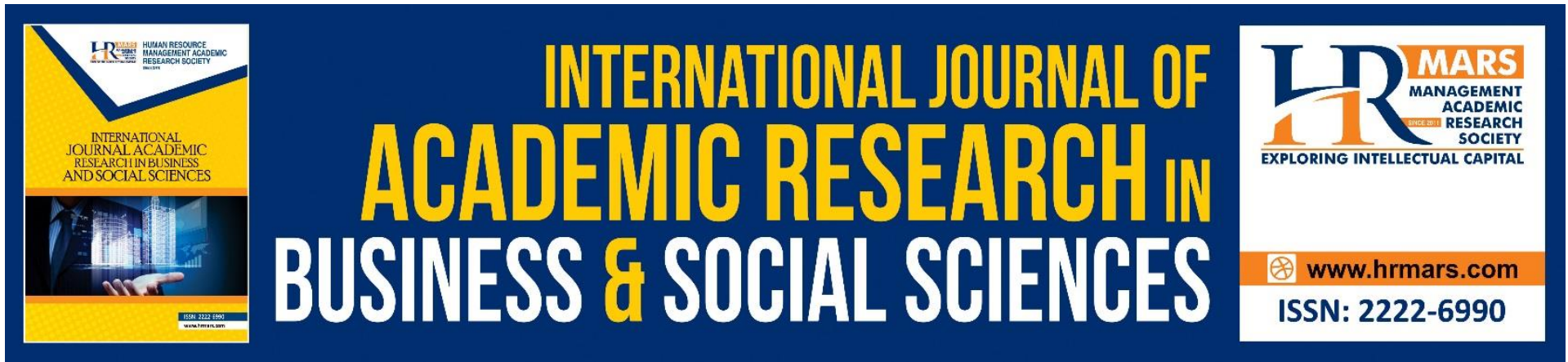

\title{
Earnings Quality at the IPOS: The Influence of Opportunistic Behaviour and Ownership Control Mechanisms
}

\author{
Zunaidah Sulong, Sharifah Nur Fazeuraida TMR, Mohd Rahim Ariffin, \\ Hartini Ab. Ghani
}

To Link this Article: http://dx.doi.org/10.6007/IJARBSS/v8-i12/5212

DOI: $10.6007 /$ IJARBSS/v8-i12/5212

Received: 07 Nov 2018, Revised: 16 Dec 2018, Accepted: 29 Dec 2018

Published Online: 29 Dec 2018

In-Text Citation: (Sulong, TMR, Ariffin, \& Ghani, 2018)

To Cite this Article: Sulong, Z., TMR, S. N. F., Ariffin, M. R., \& Ghani, H. A. (2018). Earnings Quality at the IPOS: The Influence of Opportunistic Behaviour and Ownership Control Mechanisms. International Journal of Academic Research in Business and Social Sciences, 8(12), 1265-1277.

Copyright: (C) 2018 The Author(s)

Published by Human Resource Management Academic Research Society (www.hrmars.com)

This article is published under the Creative Commons Attribution (CC BY 4.0) license. Anyone may reproduce, distribute, translate and create derivative works of this article (for both commercial and non-commercial purposes), subject to full attribution to the original publication and authors. The full terms of this license may be seen

at: http://creativecommons.org/licences/by/4.0/legalcode

Vol. 8, No. 12, 2018, Pg. 1265 - 1277

http://hrmars.com/index.php/pages/detail/IJARBSS

JOURNAL HOMEPAGE

Full Terms \& Conditions of access and use can be found at

http://hrmars.com/index.php/pages/detail/publication-ethics 


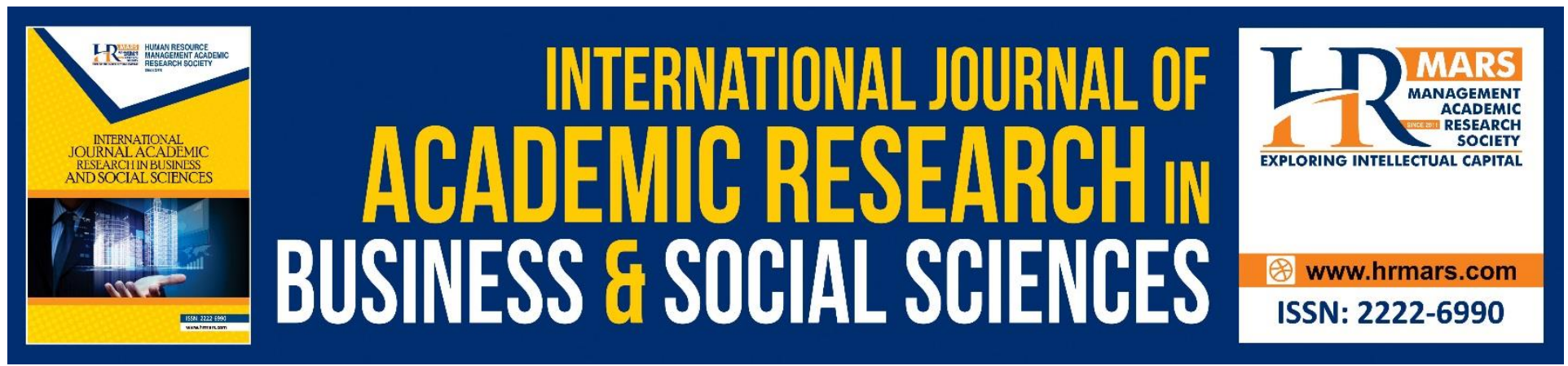

\title{
Earnings Quality at the IPOS: The Influence of Opportunistic Behaviour and Ownership Control Mechanisms
}

\author{
Zunaidah Sulong ${ }^{1, *}$, Sharifah Nur Fazeuraida TMR², Mohd Rahim \\ Ariffin $^{3}$, Hartini Ab. Ghani ${ }^{4}$ \\ $1,{ }^{*}$ Faculty of Economics and Management Sciences, Universiti Sultan Zainal Abidin \\ Corresponding Email: zunaidah@unisza.edu.my \\ ${ }^{2}$ Faculty of Economics and Management Sciences, Universiti Sultan Zainal Abidin \\ Email: sfazeuraida@yahoo.com \\ ${ }^{3}$ Faculty of Islamic Contemporary Studies, Universiti Sultan Zainal Abidin \\ Email:mrahim@unisza.edu.my \\ ${ }^{4}$ Faculty of Economics and Management Sciences, Universiti Sultan Zainal Abidin \\ Email: hartinighani@unisza.edu.my
}

\begin{abstract}
Earnings management at the time of the IPO is an important issue because it can lead investors to pay an unreasonable price for their shares. The paper reviews whether IPO firms engage in earnings management discretionary behaviour, by focusing on the accrual-based earnings management (AEM) models. It also determines on the influence of opportunistic behaviour and ownership control mechanisms towards earnings quality of IPO firms. The Jones, Modified Jones, Performance Matched, and Total Accrual Models wiil be used to investigate accrual activity behaviours in IPO firms. The quality of financial reporting in IPO firms is expected to be enhanced by limiting the opportunistic managerial discretion and ownership control mechanisms.
\end{abstract}

Keywords: Initial public offerings, Earnings management, Earning quality , Opportunistic Behaviour, Ownership Control Mechanisms 


\section{Introduction}

Initial public offering (IPO) is the offerings of the firm's shares for the first time to the public. During the subscription period the mass participation are expected, or when shares of privately held firm are available for trading on public market. Public market is known to be NESDAQ, NYSE, Malaysian Stock Exchange, etc. On the other hand, in a firm's lifecycle, initial public offering (IPO) is an important corporate event. Firm's gets earnings from their first equity sales to the public can be directed towards projects funding, starting new business line and pay off existing debt, by going public (Ozdemir, O., \& Upneja, 2016). Other than that, it is to start new projects, R\&D funding and also to expand business (Albano, 2011; Bajo, 2014; Kohli, 2015).

The investors incurred heavy losses because the firm wants to obscure their financial reports by engaging in various earnings management practices, in cases of corporate collapsed. For that reasons, the investors, regulators, other stakeholders and also government are maybe entrust the information of high quality financial statement. High earnings management practices shows that managers have handling the disclosed financial statement in order to maximize the compensation and bonuses for their own interest (Dechow, 1995). In view earnings management from opportunistic perspectives, it is benefits to the managers also it is considered as a corrupting financial manipulation (Desai et al., 2004).

To restore the investors' confidence in dealing with their equity and how public offerings, earnings management discretionary behaviour is expected to be more dominant in this period of uncertainty. Management has considerably discretion in reported earnings. Moreover, Kalgo et al. (2016) stated that it is the signal device of firm value to the investors is the

earnings. Teoh et al. (1998); a hypothesis showed that to influence IPO pricing the managers opportunistically inflate the earnings. Li (2010) stated that regarding the earnings information, it makes the investors more cautions in making investment decisions in the cases of economic collapsed and crisis. As a matter of the fact, earnings quality defined as the reports that shows the financial statement and about the company and it is crucial in assisting the decision making process.

The ownership pattern of a firm, play a significant role in term of maximizing shareholder's wealth and in disciplining managers (Jensen, 2000). Prior study has indicated that the company's performance also has positive effect of concentrated ownership (Yammeesri \& Lodhl, 2004). The firms with concentrated ownership structure should show high quality of earning stated from opportunistic behaviour hypothesis. Due to the high managers intention tend to manipulate earnings. The purpose of this paper is review on the opportunistic behaviour and ownership control mechanisms on earnings quality of Malaysian IPOs.

\section{Literature Review}

\section{Listing Structure of Malaysian IPO Market}

Share market in every country has its own unique characteristic; such in Malaysia, the mandatory requirement is thirty percent of Bumiputra and Shariah compliant status. The parties involved for IPO issuance are issuing firms, underwrites and investors in a trading system. There are two categories for the investors involved which are retail investors (individual investors) and institutional investors. Retail investors refers to uninformed investors whereas institutional investors as informed investors. 
In primary market, the distribution of new securities issues are falls upon a bank which acts as an underwriter. Commonly, firms who need to raise funds, payoff their existing debt, to get capital and etc through equities will seek advice from an investment bank.

Selling mechanism for IPOs are consists of auction, book building and fixed priced offers. As a rule, in Malaysia, fixed priced offers are used as selling mechanism in selling IPOs. In Malaysia, for a firm in going for IPOs, the application is submitted to get an approval from Ministry of International Trade and Industry (MITI) and Foreign Investment Committee (FIC). Later, Securities Commission (SC) will examine the firm's dividend and forecast profit for approval. There are three types of new issues which is public issues which also known as primary shares. Public issues are offered to the public for the first time. Ordinarily, public issues are allocated to retail investors (individual investors).as a matter of fact, this type of issuance will increase the firm's paid up capital. Under Foreign Investment Committee (FIC), a firm that goes for an IPO must meet the requirement of $25 \%$ of shares in public hands and also $30 \%$ of Bumiputra holding shares.

Next is offered for sales which is share allocated to the original shareholders (the owners), later it is offered to the public. The original shareholders (owners) are discouraged to sell shares before expiration of lock-up period. Lock-up period refers to an agreement between issuing firms and underwriter (bank) which is barred the sale of shares for a certain period of time. In case in Malaysia, the owners cannot immediately sell the shares and transfer the IPOs. This is because, the rules and regulations that imposed by Securities Commission (SC) pertaining to the sale of the shares that owned by the original shareholders (owners). Lock-up period in Malaysia is up to 3 years before they can sell shares in secondary market. Lock-up price in another country such U.S.A is around 6 months period. Third category of new issues is private placement which is offered to the institutional investors.

\section{Opportunistic Behaviour and Ownership Control Mechanisms}

The important thing about opportunistic behaviour is not such behaviour always exists, but the possibility of opportunistic behaviour is always present. Most of the people act honourably and do the right things and some people will do more than required, however, there are always a few who are without conscience and will not act in the best interest of all parties to the transaction, but rather are acting with self-interest. However, the opportunities construct only assumes that some managers may act dishonourably and precautions must be taken.

The opportunist managers may manipulate the accounting numbers in order to look good although they have negative performance to be reported as highly performed firm (Ghazali et al., 2015). Profitability and free cash flow of the firm are the term that should be discussed in the opportunistic behaviour of the manager. Indeed, an agency problem are occurs when involved surplus free cash flow that create an opportunity for the manager to manipulate earnings. This is supported by previous studies which mention that managers get their own benefit from higher cash free cash flow (Ross, 1973; Jensen \& Meckling, 1976; Jensen, 1986; Gul, 2011).

Each business entities have unique form of internal structure for held. Ownership is much closed to control in the business entities context. But ownership invested to individual or held by individual and whether those individual who only do business also have some level of control or entitled to compensation. It is vital to understand the internal structure of held ownership. Indeed, 
it can be problematic that exist between corporate executive and shareholders in an agency relationship. Currently, the ownership of the shares is highly diffused in a publicly traded corporation and the shareholders have limited direct control. Additionally, it may create a conflict with goals pursued by the managers and those desired by the shareholders (e.g. to seek maximum returns for their investment, shareholders may be willing to assume significant risk within a reasonable period of time. Such a case, managers have higher incentive by increasing disclosure to lessen information asymmetry. This is the reasons because managers have less motivation to obscure vital information from other shareholders.

Prior studies Kalgo et al. (2016) point out in most East Asian such Malaysia, expropriation of minority shareholders wealth are basically dominance by concentrated ownership which is either family, institutional or controlling shareholders. Due to increase in shareholders and creditors demand for reporting of quality, the earnings of public equity firms are higher than earnings from private equity firms (Givoly et al., 2010). What is more, since a manager from a firm with a diffuse ownership structure tends to camouflage earnings, they should present lower earnings quality based on opportunistic demand hypothesis.

\section{Earnings Management and Earnings Quality}

Definition of earnings management is "a process of taking deliberate steps within the constraints of generally accepted principles to bring about a desired level of reporting earnings" by (Davidson et al., 1987). While Schipper (1989), stated that earning management is "a purposeful intervention in the external financial reporting process, with the intent of obtaining some private gain". From CEO perspective of earnings management by Mulford \& Comiskey (2002), which is considered as good earnings management which is reasonable and exact practices that are part of operating a successful business and provide value to shareholders. While for the bad earnings management, it conceal actual operating performance which is considered unethical earnings management by making fabricated accounting entries to shows estimates beyond the point of rationality.

To value securities and encourage investors' confidence, high quality and disclosure of financial reporting is crucial. When making an investment decision, an investors, analysts, regulators and institutional owner have depend on the quality of reported earnings.

\section{Earnings Management and Earnings Quality within GAAP Framework}

Prior studies explained that part of accounting manipulation is the fraudulent of financial reporting and also the earning management practices (Schipper, 1989; Dechow et al., 1996). Furthermore, earnings management is literally bounds by Generally Accepted Accounting Practices (GAAP) and also it is also take advantage on how accounting discretion can be applied. GAAP is the guidelines or standard that permits the judgment whenever necessary. It is applicable to ensure the consistency of the financial reporting is at the minimum level. Even more, there is a space for unscrupulous distortion of financial information within GAAP even thought being a standard guideline. In other words, although there are guidelines, the malpractice in financial information reporting still happens.

This 'legal malpractice' is evolve to be named as earnings management which previously also known as income smoothing. Income smoothing is the minimizing the abnormality in the earnings so that it keeps appearing at the appropriate level to be considered as 'normal' (Beildleman, 1973). 
Besides, GAAP is by own discretion and professional judgment, is just a standard and guidelines if it is without the strictness and enforcement (Kothari et al., 2010). The reason why the manipulation happens is because of the pressure to survive through economic crisis and to measure up the performance with the previous years and also to meet the analysts' forecast. Therefore, since there is no violation of law happens, the practice is still widely accepted.

Although there are many accounting policies arise, firms still need to find the one that is suitable with their reporting needs. Some accounting policies tend to report a higher net income such as FIFO inventory costing system, straight line depreciation policy for non-current assets, and the flow-through method for accounting for income tax credits. Conversely, the practice that report lower net income are include a firm that used LIFO costing system, accelerated depreciation for noncurrent assets and the deferral method for income tax credits. Nonetheless, within the GAAP framework the practices are acceptable as accounting alternatives. The practice although brings strong debate among scholars and practitioners (including regulators), it is an unethical but still permissible and legal also acceptable for accounting alternatives by the leniency of GAAP framework (Burns \& Merchant, 1990; Maclntosh, 1995; Grasso, Tilley and White, 2009).

\section{Earnings Management and Earnings Quality within IFRS Framework}

The beginning of IFRS framework is known as the International Accounting Standards Committee (IASC), and it is the international accounting standards formed by the International Accounting Standards Board (IASB). The adoption of IFRS that has been able to improve the quality of accounting standards in most country that has been found in earlier study by Chen et al. (2010). Actually, there is a difference term that describes "IFRS convergence" and "IFRS adoption". At the state level, adoption means that the IFRS are being replaced by national accounting standards. The member countries of the European Union (EU) have taken the position since 2005 to regulate IFRS in full. In contrast, convergence means gradual mechanism to change the national standards with IFRS that conducted by a country. Regardless of it is not fully adopted; convergence has minimum disparity with IFRS.

Characterized by long tradition of stock market financing, IFRS is a shareholder-oriented accounting system in combination from common law rules such as USA or UK. It is characterized by a high level of implicit accounting choices but hardly contain explicit accounting choices (Wagenhofer, 2009). Compared to the typified Continental European system, IFRS avoids the discretion that caused the creation of hidden reserved to manipulate the earnings and to mask the economic losses. Other than that, Ballwieser (2009) stated IFRS provides more informative financial statement, incorporate economic gain and losses on timely basis, and also pursue the goal to reflect economic substance rather than legal firm. In order to lower down the information asymmetries between small and large shareholders, IFRS provides comprehensive and timely financial statements (Pae et al., 2008).

Furthermore, in minimizing the gaps that has been used by managers in performing earnings management, Malaysian Accounting Standards Board (MASB), International Accounting Standard Board (IASB) and International Financial Reporting Standard (IFRS) has created the financial reporting guidelines. Barth et al. (2008) study a sample of 327 companies from 21 countries in year 1994-2003, and its shows that the earnings management decrease significantly when adopting the IFRS of the firm. High quality of financial statement might be the result of the IFRS adoption. Doukakis, 2010 
INTERNATIONAL JOURNAL OF ACADEMIC RESEARCH IN BUSINESS AND SOCIAL SCIENCES Vol. 8, No. 12, Dec, 2018, E-ISSN: 2222-6990 @ 2018 HRMARS

argued that this is because it has an impact on the variability and persistence of income and reduction of income distribution. No evidence has been found that earnings management has become lower by adopting the IFRS and it even rising in France. This was revealed by Jeanjean \& Stolowy (2008) that examined 1146 firms from Australia, France and UK from year 2005 to 2006.

\section{Motivation for Earnings Management}

Income smoothing is an impeding the fluctuation in reported earnings over time (Ronen \& Yaari, 2008). As been explained on income smoothing by previous literature, in order to minimize the variance of reported earnings, manager has selected the accounting policies for their firm. Manager usually increasing reported earnings when there is low operating performance and decreasing the reporting earnings when operating performance is higher. The manipulation to increase the current earnings is from $8-12 \%$ of firms with small pre-managed earnings and for firm's losses in managing earning to create positive earnings, it is around $30-44 \%$ of firms with small pre-managed stated by Dichev (1997).

Manager selects alternatives accounting policies from the intention to maximize their compensation, affirmation from management compensation hypothesis (Yoon \& Miller, 2002). Managers may reduce the reported earnings when the operating performance exceeding the upper limit of bonus compensation. However, managers cannot manipulate earnings to exceed the lower limit of bonus compensation when operating performance is low, then the "big bath" strategies may be applied (Yoon \& Miller, 2002).

To protect the ownership control of firms depending on the situation, the managers will either increase or decrease the reported earnings derived from management buyout or principle of ownership control (Yoon \& Miller, 2002). Commonly, executives may raise the stakes and drive change when management buyout provides opportunity for them. But, it may be manipulated for the sake of personal interest as well. To keep their position within the firms and due to the threat of takeover, managers could increase reported earnings to convince the target shareholders to reject the offer. To reduce the buyout compensation, the managers of the firms going private tend to understate the reported income (Perry \& William, 1994).

The political cost perspective is to secure the relative political interests because of the managers may have the incentives to manage the earnings (Yoon \& Miller, 2002). In order to prevent from any spotlight on their activities, the managers will try to lower the earnings. Previous study by Jones (1991) finds that supports the political cost hypothesis and the she estimate discretionary accruals by developing a seminal model. Furthermore, to reduce political vulnerability, larger and highly profitable Malaysian firms have adopted more income decreasing accruals (Mohd. Saleh, Mohd. Iskandar, \& Rahmat, 2005).

\section{Accrual-based Earnings Management Models (AEM)}

Discretionary accruals should secure a bigger part of manipulation of manager, so that previous study will use discretionary accruals of total accruals in spite of being affirmation those discretionary current accruals that provide managers with flexibility (Jones, 1991). In the event period, earlier study has been used the total accruals from their estimation period with an assumption there is no earnings management during the estimation period (Healy, 1985; DeAngelo, 1986). There is a difference 
between the estimation of non-discretionary accruals and the total accrual in that period with amount calculation of discretionary accruals. It is being utilised on the last period of total accruals (DeAngelo, 1986). Furthermore, the measurement of earnings management is regularly explained as an inverse measure of earnings quality and it is significance to review in earnings management.

\section{The Jones Model}

To separate non-discretionary accruals and discretionary accruals using regression analysis, a new method was proposed in 1991 by Jones which relating to the economic condition of the firms. As reflected in the changes level of fixed assets and revenue in the economic condition of the firm which effected these accruals as suggested by Jones, also an assumption of its' model that non-discretionary accruals are constant over time.

In an event study of Jones's research, she assumes that the firms do not manipulate earnings before the event. The normal accruals in the estimation period are calculated as follow:

$$
\frac{N D A C_{i t}}{T A_{i t-1}}=\alpha_{i}\left[\frac{1}{T A_{i t-1}}\right]+\beta_{1}\left[\frac{\Delta R E V_{i t}}{T A_{i t-1}}\right]+\frac{\beta_{2} P P E_{i t}}{T A_{i t-1}}
$$

Equation 2(1)

Where;

$$
\begin{aligned}
N D A C_{i t}= & \text { The non-discretionary accruals year } \\
T A_{i t-1}= & \text { The total assets in year } t-1 \\
\Delta R E V_{i t}= & \text { The change in revenues in year } t \\
P P E_{i t}= & \text { The property, plant and equipment } \\
& \text { in year } t \\
\alpha_{i t}= & \text { The intercept in year } t \\
\beta_{i t}= & \text { The slope coefficient in year } t \\
i= & \text { The individual firm in year } t
\end{aligned}
$$

\section{Modified Jones Model}

In order to eliminate the tendency of speculation in Jones Model, previous researchers have made some modification to the model in measuring the discretionary accruals when the discretion is exercise over revenue (Dechow et al., 1995). During event period, the discretionary accruals are calculated by multiplying the estimated coefficient of the change in sales by the change in cash sales instead of the changes in sale which is the change in revenue minus the change in accounts receivable to estimate the discretionary accruals. This version with a novelty in the treatment of accounts receivable is known as the Modified Jones Model.

In the managers' perspective in exercising their discretion over revenue recognition, this model is the most powerful than any other model (Dechow et al., 1995; Guay, Kothari, and Watts, 1996). The equation of Modified Jones Model is as followed: 


$$
\frac{N D A C_{i t}}{T A_{i t-1}}=\alpha_{i}\left[\frac{1}{T A_{i t-1}}\right]+\beta_{1}\left[\frac{\Delta R E V_{i t}-\Delta R E C_{i t}}{T A_{i t-1}}\right]+\frac{\beta_{2} P P E_{i t}}{T A_{i t-1}}
$$

Where;

Equation 2(2)

$$
\begin{aligned}
N D A C_{i t}= & \text { The non-discretionary accruals } \\
T A_{i t-1}= & \text { The total assets in year } t-1 \\
\Delta R E V_{i t}= & \text { The change in revenues in year } t \\
\Delta R E C_{i t}= & \text { The change in receivables in year } \mathrm{t} \\
P P E_{i t}= & \text { The property, plant and } \\
& \text { equipment in } \\
& \text { year } t \\
\alpha_{i t}= & \text { The intercept in year } t \\
\beta_{i t}= & \text { The slope coefficient in year } t \\
i & =\text { The individual firm in year } t
\end{aligned}
$$

\section{Performance Matched Model}

Another model was proposed by Kothari, Leone and Wasley in 2005 which used regularly in estimating discretionary accruals. Besides, in managing discretionary accruals, firms' performance need to be taken into consideration because it's plays an importance role (Kothari et al., 2005). In addition, this model is founded by them that it is most powerful model in enhancing reliability of hypothesis than other models. Prior study are proposed and customized (include an intercept in order to mitigate heteroscedasticity and return on assets (ROA)) this model similar to other both model (Jones Model and Modified Jones Model) to affect the discretionary accruals of performance (Kothari et al., 2005). The equations as follow:

$\frac{N D A C_{i t}}{T A_{i t-1}}=\alpha_{i}\left[\frac{1}{T A_{i t-1}}\right]+\beta_{1}\left[\frac{\Delta R E V_{i t}-\Delta R E C_{i t}}{T A_{i t-1}}\right]+\frac{\beta_{2} P P E_{i t}}{T A_{i t-1}}+\beta_{3} R O A_{i t-1}$

Equation 2(3)

Where;

$N D A C_{i t}=$ The non-discretionary accruals year $t$

$T A_{i t-1}=$ The total assets in year $t-1$

$\triangle R E V_{i t}=$ The change in revenues in year $t$

$\triangle R E C_{i t}=$ The change in receivables in year $\mathrm{t}$

$P P E_{i t}=$ The property, plant and equipment in year $t$

$R O A_{i t-1}=$ The return on assets in year $t-1$

$\alpha_{i t}=$ The intercept in year $t$

$\beta_{i t}=$ The slope coefficient in year $t$ 
INTERNATIONAL JOURNAL OF ACADEMIC RESEARCH IN BUSINESS AND SOCIAL SCIENCES

Vol. 8, No. 12, Dec, 2018, E-ISSN: 2222-6990 @ 2018 HRMARS

$i=$ The individual firm in year $t$

\section{Total Accruals}

In involvement of merger and acquisition of the firms, some study has been argued that some circumstances, the approach for the balance sheet are lesser (Collins and Hribar, 1999). To compute total accruals (TA), previous studies have used balance sheet approach (Dechow et al., 1995; Jones, 1991; Kothari et al., 2005). Total accrual (TACC) is derived as follows:

$T A C C_{i t}=\frac{\left[\left(\Delta C A_{i t}-\Delta C C E_{i t}\right)-\left(\Delta C L_{i t}-\Delta S T D_{i t}\right)-D e p_{i t}\right]}{T A_{i t-1}}$

Where;

Equation 2(4)

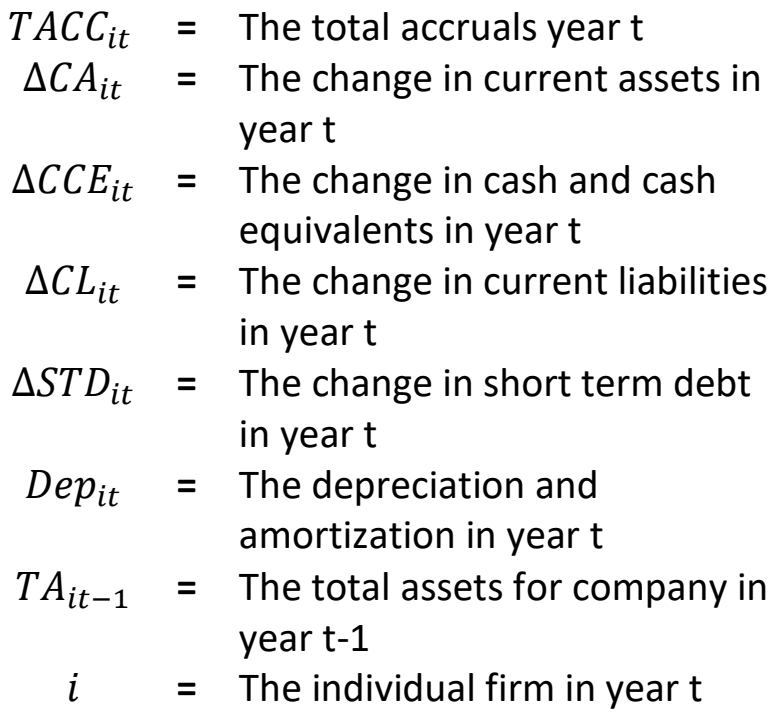

\section{Conclusion}

As a conclusion, this paper has reviewed the potential circumstances of earnings quality in the context of managerial opportunistic behaviour and ownership control mechanism in IPO firms. Based on this review, we expect that opportunistic behaviour and ownership control mechanisms will have a significant impact on financial reporting quality and agency costs. Thus, it has implications for both regulators and market participants.

\section{References}

Albano, J. M. (2011). Assessment of the Initial Public Offering. NTRC Tax Research Journal, 1-20.

Ahmad-Zaluki, N. A., Campbell, K., \& Goodacre, A. (2011). Earnings management in Malaysian IPOs: The East Asian crisis, ownership control, and post-IPO performance. International Journal of Accounting, 46, 111-137. http://dx.doi.org/10.1016/j.intacc.2011.04.001

Bajo, E. C. (2014). Underwriter Networks in Initial Public Offerings. 1-54. 
INTERNATIONAL JOURNAL OF ACADEMIC RESEARCH IN BUSINESS AND SOCIAL SCIENCES

Vol. 8, No. 12, Dec, 2018, E-ISSN: 2222-6990 @ 2018 HRMARS

Ballwieser, W. (2009): IFRS-Rechnungslegung, München.

Barth, M., Landsman, W., Lang, M. (2008). International accounting standards and accounting quality. Journal Accounting Research, 46(3), 467-498. doi: 10.1111/j.1475-679X.2008.00287.x

Beidleman, C. R. (1973). Income smoothing: The role of management. The Accounting Review, 48(4), 653-667.

Burgstahler, D., Dichev, I. (1997). Earnings management to avoid earnings decrease and losses. Journal of accounting and economics, 24(1), 99-126. https://doi.org/10.1016/S01654101(97)00017-7

Burns, W. \& Merchant, K. (1990). The dangerous morality of managing earnings. Management Accounting, 72(2), 22-25.

Chen, H., Tang, Q., Jiang, Y., \& Lin, Z. (2010). The role of international financial reporting standards in accounting quality: Evidence from the European Union. Journal of International Financial Management \& Accounting, 21(3), 220-278.

Collins, D. W., \& Hribar, P. (2000). Earnings-based and accrual-based market anomalies: one effect or two?. Journal of Accounting and Economics, 29(1), 101-123.

Davidson, R., C. Stickney, and Weil. R. (1987). 'The language of business', Seventh edition.

DeAngelo, L. E. (1986). Accounting numbers as market valuation substitutes: A study of management buyouts of public stockholders. Accounting review, 400-420.

Dechow, P. M., Sloan, R. G., \& Sweeney, A. P. (1996). Causes and consequences of earnings manipulation: An analysis of firms subject to enforcement actions by the SEC. Contemporary Accounting Research, 13(1), 1-36,

Dechow, P. M., Sloan, R. G., \& Sweeney, A. P. ( 1995). Detecting earnings management. Accounting review, 70, 193-225.

Desai, M. A., Foley, C. F., \& Hines, J. R. (2004). A multinational perspective on capital structure choice and internal capital markets. The Journal of Finance, 59(6), 2451-2487.

Doukakis, L. C. (2010). The persistence of earnings and earnings components after the adoption of IFRS. Managerial Finance, 36(11),

969980.http://dx.doi.org/10.1108/03074351011081286

Ghazali, A. W., Shafie, N. A., \& Sanusi, Z. M. (2015). Earnings Management: An Analysis of Opportunistic Behaviour, Monitoring Mechanism and Financial Distress. Procedia Economics and Finance, 28, 190-201.

Givoly, D., Hayn, C. K., \& Katz, S. P. (2010). Does Public Ownership of Equity Improve Earnings Quality?. The Accounting Review, 85(1), 195-225.

Grasso, L. P., Tilley, P. A., \& White, R. A. (2009). The ethics of earnings management: Perceptions after Sarbanes-Oxley. Management Accounting Quarterly, 11(1).

Guay, W. R., Kothari, S. P., \& Watts, D. L. (1996). A market-based evaluation of discretionary accruals models. Journal of accounting research, 83-105.

Gul, F. A., \& Tsui, J. S. (2001). Free cash flow, debt monitoring, and audit pricing: Further evidence on the role of director equity ownership. Auditing: A Journal of Practice \& Theory, 20(2), 71-84.

Healy, P.M. (1985). The effect of bonus schemes on accounting decisions. Journal of Accounting and Economics 7, 85-107. 
INTERNATIONAL JOURNAL OF ACADEMIC RESEARCH IN BUSINESS AND SOCIAL SCIENCES

Vol. 8, No. 12, Dec, 2018, E-ISSN: 2222-6990 @ 2018 HRMARS

Jeanjean, T., \& Stolowy, H. (2008). Do accounting standards matter? An exploratory analysis of earnings management before and after IFRS adoption. Journal of accounting and public policy, 27(6), 480-494. http://dx.doi.org/10.1016/j.jaccpubpol.2008.09.008

Jensen, M. C. (1986). Agency costs of free cash flow, corporate finance, and takeovers. The American Economic Review, 76(2), 323-329.

Jensen, M.C. (2000). A Theory of the Firm: Governance, Residual Claims, and Organizational Forms. Harvard University Press, Cambridge.

Jensen, M. C., \& Meckling, W. H. (1976.) Theory of the firm: Managerial behavior, agency costs and ownership structure. Journal of financial economics, 3(4), 305-360.

Jones, J. (1991). Earnings management during import relief investigations. Journal Accounting Research, 29, 193-228.

Kalgo, S. H., Nordin, B. A. A. Nahar, H. S., \& Turmin, S. Z. (2016). Real and Accrual Earnings Management, Does Ownership Retention Matters? Evidence from Emerging Market IPOs. Research Journal of Finance and Accounting, 7(11), 62-79.

Kohli, A., \& Sharma, J. K. (2015). Survey of Corporate Financial Behavior of Indian MNCs. International Journal of Finance and Accounting Studies, 3(1), 12-27.

Kothari, S. P., Leone, A. J., \& Wasley, C. E. (2005). Performance matched discretionary accrual measures. Journal of accounting and economics, 39(1), 163-197.

Kothari, S. P., Ramanna, K., \& Skinner, D. J. (2010). Implications for GAAP from an analysis of positive research in accounting. Journal of Accounting and Economics, 50(2), 246-286.

$\mathrm{Li}, \mathrm{Y}$. (2010). The Case Analysis of the Scandal of Enron. International Journal of Business and Management, 5(10), 37-41.

Macintosh, N. B. (1995). The ethics of profit manipulation: a dialectic of control analysis. Critical perspectives on accounting, 6(4), 289-315.

Mulford, C. W., \& Comiskey, E. E. (2002): The Financial Numbers Game, Detecting Creative Accounting Practices. New York : John Wiley \& Sons, Inc.

Mohd. Saleh, N., Mohd. Iskandar, T., \& Rahmat, M. M. (2005). Earnings management and board characteristics: Evidence from Malaysia. Jurnal Pengurusan, 24, 77-103.

Ozdemir, O. \& Upneja, A. The role of internationalization on the IPO performance of service firms: Examination of initial returns, long-run returns, and survivability. International Business Review, 25(5): 997-1009, 2016. http://dx.doi.org/10.1016/j.ibusrev.2016.01.009

Pae, J. / Thornton, D.B. / Welker, M. (2008). Agency Cost Reduction Associated with EU Financial Reporting Reform. Journal of International Accounting Research, 7 (1), 51-76.

Perry, S. E., \& Williams, T. H. (1994). Earnings management preceding management buyout offers. Journal of Accounting and Economics, 18(2), 157-179.

Ronen, J., \& Yaari, V. (2008). Earnings management: emerging insights in theory, practice, and research (Vol. 3). New York: Springer Verlag.

Ross, S. A. (1973). The economic theory of agency: The principal'sproblem. The American Economic Review, 63(2), 134-139.

Schipper, K. (1989). Commentary on earnings management. Accounting Horizons 3, 91-102.

Teoh, S. H., Welch, I., \& Wong, T. J. (1998). Earnings management and the long-run market performance of initial public offerings. The Journal of Finance, 53(6), 1935-1974. 
INTERNATIONAL JOURNAL OF ACADEMIC RESEARCH IN BUSINESS AND SOCIAL SCIENCES

Vol. 8, No. 12, Dec, 2018, E-ISSN: 2222-6990 C 2018 HRMARS

Wagenhofer, A. (2009): Internationale Rechnungslegungsstandards - IAS/IFRS: Grundlagen und Grundsätze - Bilanzierung, Bewertung und Angaben - Umstellung und Analyse, München.

Yammeesri, J., \& Lodh, S. C. (2004). Is family ownership a pain or gain to firm performance. Journal of American Academy of Business, 4(1/2), 263-270.

Yoon, S. S., \& Miller, G. A. (2002). Cash firm operations and earnings management in Korea. The International Journal of Accounting, 37(4), 395-412. 